\title{
Anticancer Activity against Breast Cancer Cells T47D and Identification of Its Compound from Extracts and Fractions of Leaves Bamboo Grass (Lophaterum gracile B.)
}

\author{
Alfi Istiqomah ${ }^{1}$, Roihatul Muti' ${ }^{2}{ }^{2}$, Elok Kamilah Hayati ${ }^{1}$ \\ ${ }^{1}$ Jurusan Kimia Fakultas Sains dan Teknologi Universitas Islam Negeri Maulana Malik Ibrahim Malang \\ ${ }^{2}$ Jurusan Farmasi Fakultas Sains dan Teknologi Universitas Islam Negeri Maulana Malik Ibrahim Malang \\ Email: eloksunardji@gmail.com
}

\begin{abstract}
Bamboo grass (Lophatherum gracile B.) is one of weed plants which frequently used as a medicine because it provides active compounds, for instance steroids and tannins. This research was conducted to determine the anticancer activity of extracts and fractions of leaves bamboo grass in inhibiting the growth of breast cancer cells T47D, and to determine the class of the active compounds contained in extracts and fractions which have the lowest $\mathrm{IC}_{50}$ value from phytochemical test and identification with UV-Vis instruments and FTIR. The extraction of active compound leaves of bamboo grass is done by maceration method using ethanol $80 \%$, hydrolysis and partition with n-hexane and chloroform. Four of the extracts is phytochemical tested and anticancer activity tested towards breast cancer cells T47D with MTT method. The best results of the test activities are performed by the separation of classes of active compounds KLTP and are identified using UV-Vis spectrophotometer and FTIR. The value of $\mathrm{IC}_{50}$ from $80 \%$ ethanol extraction is 321,389 , from hydrolysis extraction is 481.984 , from the fraction of chloroform is 177.852 , and from n-hexane fraction is $300.681 \mu \mathrm{g} /$ $\mathrm{mL}$. The lowest IC50 which have the best cytotoxic is the fraction of chloroform and $\mathrm{n}$-hexane. The results of phytochemical test fractions of chloroform and $n$-hexane fraction indicates the tannin and steroids. The identification result by using UV-Vis and FTIR shows that the fraction of chloroform and n-hexane fraction is containing tannin, which isproven by maximum wavelength at $331.6 \mathrm{~nm}$ and $331.6 \mathrm{~nm}$ allegations of $-\mathrm{OH}, \mathrm{CH}$, $\mathrm{C}=\mathrm{C}$. Moreover, the existence of steroid compounds in fraction chloroform and $\mathrm{n}$-hexane is shown by the absorption at $279.1 \mathrm{~nm}$ and $278.0 \mathrm{~nm}$ of wavelength with allegations of $-\mathrm{OH}, \mathrm{CH}, \mathrm{C}=\mathrm{C}, \mathrm{C}-\mathrm{O}$.
\end{abstract}

Keywords: bamboo grass leaves (Lophaterum gracile B.), breast cancer cells T47D, in vitro, MTT method.

\begin{abstract}
Abstrak
Rumput bambu termasuk gulma yang dapat dimanfaatkan sebagai obat, karena adanya kandungan senyawa aktif yang berperan di dalamnya, diantaranya adalah steroid dan tanin. Penelitian ini dilakukan untuk mengetahui aktivitas antikanker dari ekstrak dan fraksi daun rumput bambu dalam menghambat pertumbuhan sel kanker payudara T47D dan untuk mengetahui golongan senyawa aktif yang terkandung dalam ekstrak dan fraksi yang memiliki nilai IC50 terendah dari hasil uji fitokimia serta identifikasi dengan instrumen UV-Vis dan FTIR. Ekstraksi senyawa aktif daun rumput bambu dilakukan dengan metode maserasi menggunakan pelarut etanol 80 $\%$, hidrolisis dan ekstraksi cair-cair dengan n-heksana dan kloroform. Keempat ekstrak diuji fitokimia dan diuji aktivitas antikanker terhadap sel kanker payudara T47D dengan metode MTT. Hasil terbaik dari uji aktivitas dilakukan pemisahan golongan senyawa aktif dengan KLTP dan diidentifikasi menggunakan spektrofotometer UV-Vis dan FTIR. Nilai IC50 ekstrak dan fraksi daun rumput bambu yaitu ekstrak etanol $80 \%$, hasil hidrolisis, fraksi kloroform dan fraksi n-heksana berturut-turut 321,4; 482,0; 177,8 dan 300,7 $\mu \mathrm{g} / \mathrm{mL}$. Aktivitas terbaik atau nilai IC50 terendah adalah adalah fraksi kloroform dan fraksi n-heksana. Hasil uji fitokimia dari fraksi kloroform dan fraksi n-heksana menunujukkan adanya senyawa tanin dan steroid. Hasil identifikasi dengan spektrofotometer UV-Vis dan FTIR menunjukkan bahwa fraksi kloroform dan fraksi n-Heksana mengandung tanin ditunjukkan dengan panjang gelombang maksimum pada 331,6 nm dan 331,6 nm dengan dugaan adanya gugus $-\mathrm{OH}, \mathrm{C}-\mathrm{H}, \mathrm{C}=\mathrm{C}$, selain itu adanya senyawa steroid pada fraksi kloroform dan $\mathrm{n}$-Heksana ditunjukkan dengan serapan pada panjang gelombang $279,1 \mathrm{~nm}$ dan $278,0 \mathrm{~nm}$ dengan dugaan adanya gugus $-\mathrm{OH}, \mathrm{C}-\mathrm{H}, \mathrm{C}=\mathrm{C}$, C-O.
\end{abstract}

Kata kunci: Daun rumput bambu (Lophaterum gracile B.), sel kanker payudara T47D, in vitro, metode MTT. 


\section{PENDAHULUAN}

Kanker merupakan pertumbuhan sel secara tidak normal yang tumbuh secara cepat dan tidak terkontrol yang menyusup ke jaringan tubuh normal sehingga mempengaruhi fungsi tubuh. Berdasarkan data IARC (2010) kanker payudara merupakan penyebab kematian kanker utama kedua pada perempuan, selama 5 tahun terakhir, sejak tahun 2008 ada sekitar 1,38 juta kasus kanker payudara dimana sekitar 458 ribu mengalami kematian, sedangkan di Indonesia ada sekitar 40 ribu kasus dan 20 ribu diantaranya mengalami kematian.

Indonesia merupakan negara yang kaya sumber daya alam. Banyak tumbuhtumbuhan yang dapat dimanfaatkan sebagai obat, karena adanya kandungan bahan aktif, namun penggunaan tanaman sebagai salah satu alternatif pencegahan dan penyembuhan kanker masih membutuhkan penelitian lebih lanjut. Keanekaragaman hayati yang dimiliki Indonesia merupakan salah satu nikmat yang diberikan oleh Allah SWT, dimana setiap segala sesuatu yang diciptakan akan memberikan manfaat bagi makhlukNya, sehingga manusia patut bersyukur dan memanfaatkannya dengan sebaik-baiknya. Sebagaimana firman Allah SWT dalam al Quran surat Taha ayat 53.

Allah menumbuhkan berbagai macam tanaman yang salah satunya dapat dimanfaatkan sebagai obat, obat tersebut tidak akan diketahui manusia jika tidak benar-benar memikirkannya. Hal inilah yang menuntun manusia untuk terus mencari dan menemukan obat dari suatu penyakit. Salah satu usahanya adalah dengan eksplorasi senyawa aktif dari bahan alaam.

Rumput bambu (Lophaterum gracile B.) merupakan salah satu tanaman liar yang dapat dijadikan sebagai alternatif bahan pengobatan dan pencegahan antikanker. Daun merupakan bagian yang mudah didapatkan, tidak memerlukan banyak tanaman, dan pertumbuhannya yang lebih terhindar dari ancaman virus maupun penyakit. Kusumawati, dkk., (2003) menyatakan terdapat flavonoid pada bagian daun sedangkan pada bagian akar terdapat steroid dan triterpenoid. Identifikasi yang dilakukan Jing, dkk., (2009) terhadap daun rumput bambu menunjukkan adanya senyawa flavonoid dan triterpenoid. Ekstrak etanol dari daun rumput bambu menunjukkan adanya triterpenoid, tanin dan alkaloid (Sari, 2014).

Penelitian Sari (2014) tentang uji sitotoksik daun rumput bambu dengan variasi pelarut melalui metode BSLT didapatkan nilai $\mathrm{LC}_{50}$ dari uji BSLT pada ekstrak etanol adalah 25,2189 ppm, sehingga ekstrak tersebut mempunyai sifat toksik, didukung dengan Mc. Laughin (1991) juga menjelaskan bahwa apabila suatu ekstrak memiliki nilai $\mathrm{LC}_{50}<30 \mathrm{ppm}$ maka ekstrak tersebut berpotensi sebagai antikanker (sitotoksik). Restasari, dkk., (2009) menunjukkan bahwa ekstrak kloroform daun ketapang yang mengandung alkaloid, triterpenoid dan steroid berpotensi sebagai antikanker dengan harga $\mathrm{LC}_{50}$ sebesar 3,22 ppm.

Pembuktikan efek sitotoksik terhadap sel kanker dilakukan dengan metode MTT untuk mengetahui aktifitas biologi secara langsung dari senyawa kompleks, selain itu metode MTT relatif lebih murah, mudah dilakukan, hanya membutuhkan peralatan sederhana dan interpretasi hasilnya relatif mudah dan akurat (Kusumaningtyas, dkk., 2008). Sel kanker payudara T47D memiliki kemampuan replikasi yang tidak terbatas, homogenitas yang tinggi serta mudah diganti dengan frozen stock jika terjadi kontaminasi (Burdall, dkk., 2003).

Identifikasi senyawa aktif dilakukan dengan UV-VIS dan FTIR untuk memperoleh panjang gelombang maksimum dari senyawa sehingga dapat diketahui transisi elektron yang dilihat dari jenis ikatan pada gugus fungsinyaserta untuk mengetahui gugus-gugus fungsi dari suatu senyawa. 
Berdasarkan kajian di atas, maka dalam penelitian ini akan dilakukan pengujian aktivitas antikanker menggunakan metode MTT ekstrak dan fraksi daun rumput bambu secara in vitro terhadap sel kanker payudara T47D. Penelitian ini menggunakan sampel kering daun rumput bambu. Pemisahan senyawa aktif daun rumput bambu dilakukan dengan metode ekstraksi maserasi menggunakan pelarut etanol $80 \%$. Ekstrak pekat etanol 80 $\%$ yang diperoleh selanjutnya dihidrolisis, ekstrak hasil hidrolisis dipartisi dengan pelarut kloroform dan dipartisi dengan pelarut n-heksana. Keempat ekstrak yang diperoleh dipekatkan lalu dilakukan uji aktivitas terhadap sel kanker payudara T47D. Sampel yang memiliki bioaktifitas paling optimal dipisahkan menggunakan KLTP dilanjutkan dengan identifikasi golongan senyawa aktif dengan UV-Vis dan FTIR.

\section{METODE PENELITIAN Alat Penelitian}

Alat-alat yang digunakan diantaranya ayakan 100 mesh, oven, loyang, cawan penguap, desikator, neraca analitik, penjepit kayu, aluminium foil, shaker incubator, kertas saring, klem dan statif, penyaring buchner, corong pisah, rotary evaporator, vortex, seperangkat alat gelas laboratorium, 96-well plate, Conical Tube, Yellow tip, Blue tip, Culture Dish, Hemocytometer, ELISA reader, plat silika gel $\mathrm{F}_{254}$, bejana pengembang, lampu UV. Instrument UV-Vis Shimadzu 160-A dan FTIR Shimadzu. Sampel yang digunakan dalam penelitian ini adalah daun rumput bambu

\section{Bahan}

n-heksana, etanol 80\%, kloroform, aquades, larutan $\mathrm{HCl} 2 \%$, larutan metanol $50 \%$, logam $\mathrm{Mg}$, larutan $\mathrm{FeCl}_{3}$, reagen Dragendrofff, reagen Meyer, pereaksi Lieberman Burchard, latutan $\mathrm{H}_{2} \mathrm{SO}_{4}$ pekat, larutan formaldehid 3\%, Na-asetat, PBS, tripsin-EDTA $1 \mathrm{x}$ (tripsin $0,25 \%$ ), media kultur RPMI, DMSO, MTT $5 \mathrm{mg} / \mathrm{mL}$ (50 mg MTT dan $10 \mathrm{~mL}$ PBS), SDS $10 \%$ dalam $0,1 \mathrm{~N} \mathrm{HCl}, \mathrm{NaHCO}_{3}$.

\section{Preparasi Sampel}

Dicuci sampel daun rumput bambu hingga bersih lalu dikeringanginkan dan dipotong kecil-kecil. Sampel yang sudah kering dihaluskan dengan blender hingga halus (serbuk) dan diayak dengan ayakan 60 mesh. Serbuk yang diperoleh merupakan sampel penelitian yang kemudian ditentukan kadar airnya

\section{Analisis Kadar Air}

Dipanaskan cawan pada suhu $105{ }^{\circ} \mathrm{C}$ selama \pm 15 menit lalu didinginkan di dalam desikator selama 10 menit. Cawan ditimbang dan diulangi perlakuan sampai diperoleh berat konstan. Sampel ditimbang sebanyak $5 \mathrm{~g}$ dan dipanaskan dalam oven pada suhu $105{ }^{\circ} \mathrm{C}$ selama 1 jam. Sampel kering kemudian didinginkan dalam desikator selama \pm 15 menit dan ditimbang kembali. Perlakuan ini diulangi sampai tercapai berat konstan. Kadar air dihitung menggunakan rumus:

$$
\text { Kadar air }=\frac{(b-c)}{(b-a)} \times 100 \%
$$

Keterangan:

$\mathrm{a}=$ berat konstan cawan kosong.

$\mathrm{b}=$ berat cawan + sampel sebelum dikeringkan.

$\mathrm{c}=$ berat konstan cawan + sampel setelah dikeringkan

\section{Ekstraksi senyawa Aktif}

Ditimbang serbuk daun rumput bambu $200 \mathrm{~g}$, dimasukkan dalam 4 erlenmayer $500 \mathrm{~mL}$ berbeda masing-masing 50 g. Hasil penimbangan diekstraksi dengan perendaman menggunakan $250 \mathrm{~mL}$ pelarut etanol $80 \%$ pada setiap erlenmeyer selama 24 jam, lalu diaduk dengan bantuan shaker berkecepatan 120 rpm selama 2 jam. Kemudian disaring dengan corong Buchner 
dan ampas yang diperoleh dimaserasi kembali dengan pelarut yang sama sampai filtrat berwarna bening. Filtrat yang diperoleh digabung dan dipekatkan dengan rotary evaporator vaccum hingga diperoleh ekstrak pekat etanol.

Ekstrak pekat etanol dibagi menjadi 2 bagian yaitu: Bagian pertama, sebanyak 1 g ekstrak kasar etanol yang diperoleh dari pemekatan. Bagian kedua, ekstrak pekat etanol dihidrolisis dengan ditambahkan $\mathrm{HCl} 2 \mathrm{~N} \quad(1: 2)$ kemudian diaduk menggunakan magnetic stirrer hot plate selama 2 jam pada suhu ruang. Ekstrak hasil hidrolisis yang diperoleh ditambahkan dengan natrium bikarbonat sampai diperoleh $\mathrm{pH}$ netral yang ditandai dengan tidak terbentuknya gelembung udara.

Ekstrak etanol hasil hidrolisis dibagi menjadi 3 bagian yaitu: Bagian pertama, ditimbang dan disimpan untuk uji lanjutan. Bagian kedua, ekstrak etanol hasil hidrolisis diekstraksi cair-cair dengan kloroform, fraksi kloroform yang diperoleh dikumpulkan menjadi satu dan dipekatkan dengan rotary evaporator vaccum. Bagian ketiga, ekstrak etanol hasil hidrolisis diekstraksi cair-cair dengan pelarut nheksana, fraksi n-heksana yang diperoleh dikumpulkan menjadi satu dan dipekatkan dengan rotary evaporator vaccum.

\section{Uji Fitokimia dengan Uji Reagen}

Metode uji fitokimia dilakukan untuk mengetahui kandungan metabolit sekunder didalam daun rumput bambu dari masing-masing ekstrak dan fraksi. Ekstrak dan fraksi daun rumput bambu dilarutkan dengan sedikit masing-masing pelarutnya dan dibuat konsentrasi sebesar 10.000 ppm, kemudian dilakukan uji alkaloid, flavonoid, tanin, saponin, triterpenoid dan steroid.
Uji aktivitas Antikanker dengan Metode MTT

Uji aktivitas dilakukan dengan beberapa tahapan yaitu: penyiapan sel, perhitungan sel, peletakan sel pada plate, pembuatan dan pemberian larutan sampel, pemberian larutan MTT, pembacaan absorbansi dengan ELISA reader, analisis probit hasil dengan SPSS.

\section{Pemisahan Senyawa Aktif dengan KLTP}

Pemisahan senyawa aktif dengan KLTP dilakukan pada ekstrak yang memiliki hasil terbaik dari uji aktivitas antikanker (nilai $\mathrm{IC}_{50}$ paling kecil) dan golongan senyawanya positif pada uji reagen. Pemisahan dengan KLT preparatif ini digunakan plat silica gel $\mathrm{GF}_{254}$ dengan ukuran 10 x $20 \mathrm{~cm}$. Ekstrak pekat ditotolkan sepanjang plat pada jarak $1 \mathrm{~cm}$ dari garis tepi bawah dan $1 \mathrm{~cm}$ dari garis tepi atas. Selanjutnya dielusi dengan menggunakan eluen n-heksana: etil asetat (6:4) untuk tanin, dan eluen n-heksana: etil asetat (7:3) untuk steroid. Noda-noda pada permukaan plat diperiksa dibawah sinar UV pada panjang gelombang $254 \mathrm{~nm}$ dan 366 $\mathrm{nm}$,

\section{Identifikasi Golongan Senyawa Aktif}

Identifikasi dengan UV-Vis dilakukan terhadap isolat yang diperoleh dari KLTP dan diduga senyawa tanin dan steroid. Isolat dilarutkan dengan etanol, dimasukkan ke dalam kuvet dan diindentifikasi pada panjang gelombang $200-800 \mathrm{~nm}$. Spektra dan hasil absorbansi yang diperoleh dicatat dan dianalisis, sedangkan identifikasi dengan FTIR dilakukan terhadap isolat yang telah diuapkan dari pelarutnya. Isolat ditambahkan pada pellet $\mathrm{KBr}$, didiamkan, lalu dibuat spektrum FTIR pada rentang bilangan gelombang $4000 \mathrm{~cm}^{-1}$ $400 \mathrm{~cm}^{-1}$. 


\section{HASIL DAN PEMBAHASAN Preparasi Sampel}

Preparasi sampel merupakan suatu tahapan dalam analisis bahan alam yang terdiri dari proses pencucian, pengeringan dan penyerbukan sampel. Pencucian bertujuan untuk menghilangkan kotoran yang berupa tanah yang menempel pada daun rumput bambu. Pengeringan dilakukan untuk mengurangi kandungan air dalam daun rumput bambu, meminimalkan kerusakan akibat degradasi oleh mikroorganisme/tumbuhnya jamur. Pengeringan dilakukan dengan cara diangin-anginkan yang tidak akan cepat menguap.

Sampel yang telah kering dihaluskan untuk memperkecil ukuran sampel. Semakin kecil bentuk sampel maka semakin besar luas permukaannya maka terjadinya kontak dengan pelarut dalam proses ekstraksi akan semakin besar, sehingga proses ekstraksi akan semakin cepat. Dlanjutkan dengan pengayakan menggunakan ayakan 60 mesh untuk menseragamkan ukuran serbuk

\section{Analisis Kadar Air}

Pengukuran kadar air dalam suatu sampel sangat diperlukan sebagai tahap awal dalam melakukan sebuah penelitian bahan alam, jika kadar air terlalu tinggi maka jamur akan mudah mengkontaminasi sampel dan menghalangi masuknya pelarut kedalam sampel sebab apabila pelarut yang digunakan tidak dapat bercampur dengan air maka pelarut tidak akan bisa masuk kedalam dinding sel. Tingginya kadar air sampel juga dapat berakibat tumbuhnya jamur-jamur penghasil mikotoksin (racun) yang dapat menyebabkan data yang tidak akurat pada uji aktivitas sebab kematian sel kanker bukan dikarenakan ekstrak melainkan karena jamur-jamur yang tumbuh.
Berdasarkan hasil pengukuran kadar air, diperoleh kandungan air pada sampel daun rumput bambu setelah dikeringkan sebesar $8,4332 \%(b / b)$.

\section{Ekstraksi Senyawa Aktif daun Rumput Bambu}

Maserasi adalah salah satu metode pemisahan senyawa dengan cara perendaman menggunakan pelarut organik pada temperatur ruangan. Prinsip dari metode maserasi adalah terdapat waktu kontak yang cukup antara pelarut dengan sampel yang diekstrak dengan demikian pelarut akan menembus dinding sel dan masuk ke dalam rongga sel yang mengandung zat aktif. Zat aktif akan larut, karena adanya perbedaan konsentrasi antara larutan zat aktif di dalam sel dengan yang di luar sel, maka larutan yang terpekat didesak ke luar.

Filtrat dan residunya dipisahkan dengan cara disaring menggunakan corong Buchner dan kertas saring. Filtrat yang diperoleh kemudian dipekatkan dengan vacuum rotary evaporator. Pelarut yang masih bersisa dalam ekstrak diuapkan dengan gas $\mathrm{N}_{2}$. Ekstrak pekat yang diperoleh dibagi menjadi 2 , yang pertama ditimbang sebanyak $1 \mathrm{~g}$ sebagai sampel uji dan sisanya sebanyak 22,1966 g dihidrolisis.

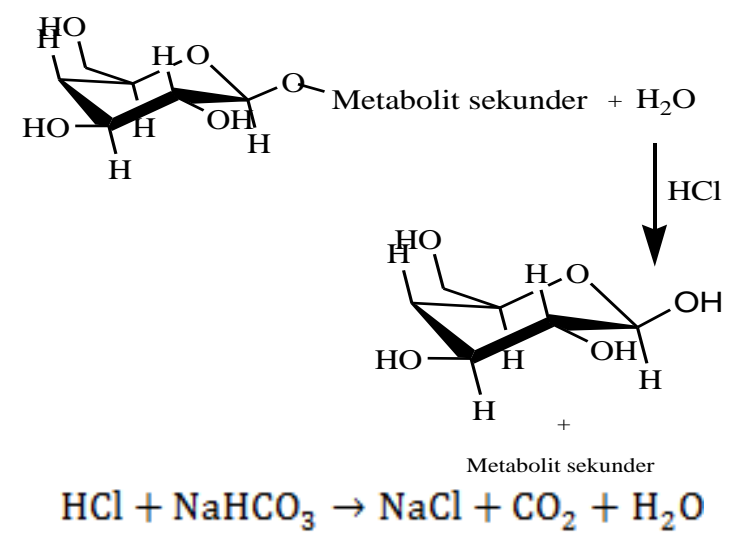

Gambar 1 Dugaan reaksi hidrolisis ikatan $O$ glikosida (Nihlati, dkk., 2008) 
Proses hidrolisis asam menggunakan larutan $\mathrm{HCl} 2 \mathrm{~N}$ pada ekstrak kasar etanol $80 \%$ daun rumput bambu. Prinsip hidrolisis asam adalah peruraian suatu senyawa dengan cara memutus ikatan glikosida menggunakan air dan katalis asam. Pada penelitian ini menggunakan larutan $\mathrm{HCl} 2 \mathrm{~N}$ sebagai katalis asam dan natrium bikarbonat jenuh sebagai penetral (Kaur and Murphy, 2012). Reaksi pemutusan ikatan glikosida yang terjadi ketika penambahan larutan $\mathrm{HCl}$ dan penetralan dengan natrium bikarbonat ditunjukkan pada Gambar 1.

Ekstraksi selanjutnya adalah ekstraksi cair-cair (partisi) antara hasil hidrolisis dengan pelarut kloroform dan nheksana. Tujuan proses ekstraksi cair-cair ini adalah untuk mendapatkan ekstrak yang lebih spesifik sifat kepolarannya. Pada ekstraksi cair-cair dengan kloroform terbentuk 2 lapisan yang tidak saling campur. Pada lapisan atas adalah fraksi atanol-air (hijau kecoklatan) dan lapisan bawah fraksi kloroform (hijau pekat). Perbedaan massa jenis pelarut mengakibatkan fraksi kloroform berada dibawah karena massa jenis kloroform $(1,498 \mathrm{~g} / \mathrm{mL})$ lebih besar dari pada massa jenis etanol $(0,789 \mathrm{~g} / \mathrm{mL})$. ekstrak hasil hidrolisis dengan n-heksana juga dihasilkan dua lapisan organik. Lapisan atas fraksi nheksana (coklat pekat) dan lapisan bawah fraksi etanol-air (coklat sangat pekat). Fraksi n-heksana berada di atas karena nheksana mempunyai massa jenis 0,695 $\mathrm{g} / \mathrm{mL}$.

\section{Uji Kandungan Golongan Senyawa Aktif dengan Reagen}

Tabel 1 Identifikasi kandungan golongan senyawa aktif yang terdapat pada ekstrak dan fraksi daun rumput bambu

\begin{tabular}{|c|c|c|c|c|c|}
\hline \multirow[b]{2}{*}{$\begin{array}{c}\text { Golongan } \\
\text { senyawa } \\
\text { aktif }\end{array}$} & \multicolumn{4}{|c|}{ Sampel Uji } & \multirow[b]{2}{*}{$\begin{array}{l}\text { Keterangan } \\
\text { Hasil Positif }\end{array}$} \\
\hline & $\begin{array}{c}\text { Ekstrak } \\
\text { Etanol } 80 \%\end{array}$ & $\begin{array}{c}\text { Ekstrak } \\
\text { hasil } \\
\text { Hidrolisis }\end{array}$ & $\begin{array}{c}\text { Fraksi } \\
\text { Kloroform }\end{array}$ & $\begin{array}{l}\text { Fraksin- } \\
\text { heksana }\end{array}$ & \\
\hline Flavonoid & - & - & - & - & - \\
\hline $\begin{array}{l}\text { Alkaloid } \\
\text { - Dragendrof }\end{array}$ & + & ++ & - & - & $\begin{array}{c}\text { Endapan } \\
\text { jingga }\end{array}$ \\
\hline - Mayer & + & ++ & - & - & $\begin{array}{c}\text { Endapan } \\
\text { kekuningan }\end{array}$ \\
\hline Tanin $\mathrm{FeCl}_{3}$ & +++ & ++ & +r+ & + & $\begin{array}{c}\text { Hijau } \\
\text { kehitaman }\end{array}$ \\
\hline Saponin & - & - & - & - & - \\
\hline Triterpenoid & +++ & ++ & - & - & $\begin{array}{c}\text { Cincin } \\
\text { kecoklatan }\end{array}$ \\
\hline Steroid & - & - & +r+ & +++ & $\underset{\text { kebiruan }}{\text { Hijau }}$ \\
\hline
\end{tabular}

Keterangan :

+++ : terkandung senyawa lebih banyak/warna sangat pekat tanda

++ : terkandung senyawa lebih /warna cukup pekat

$+\quad$ : terkandung senyawa/warna muda tanda

- $\quad$ : tidak terkandung senyawa/tidak terbentuk warna

Uji reagen dilakukan untuk mengetahui kandungan golongan senyawa aktif yang terdapat dalam ekstrak dan fraksi daun rumput bambu. Hasil dari identifikasi kandungan golongan senyawa aktif yang terdapat pada ekstrak dan fraksi daun rumput bambu ditunjukkan dalam Tabel 1 .

\section{Uji aktivitas antikanker ekstrak dan fraksi daun rumput bambu}

Pengujian antikanker dilakukan untuk mengetahui aktivitas dari ekstrak dan fraksi daun rumput bambu (Lophaterum gracile B.) dalam menghambat atau membunuh pertumbuhan sel kanker payudara dengan menggunakan berbagai variasi konsentrasi yaitu 1000, 500, 250, 125, 62.5, 31.25 dan $15.625 \mu \mathrm{g} / \mathrm{mL}$. Uji aktivitas antikanker dilakukan secara in-vitro terhadap sel kanker payudara T47D dengan metode MTT. 


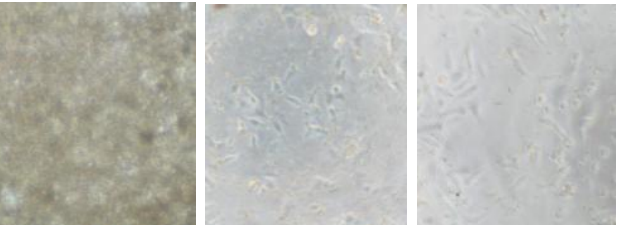

Gambar 2 (a) ekstrak kloroform konsentrasi $1000 \mu \mathrm{g} / \mathrm{mL}$, (b) ekstrak kloroform konsentrasi $125 \mu \mathrm{g} / \mathrm{mL}$ dan (c) ekstrak kloroform konsentrasi $15,625 \mu \mathrm{g} / \mathrm{mL}$

Pengamatan morfologi sel dilakukan setelah ditreatment di bawah mikroskop inverted pada setiap variasi konsentrasi sampel uji. Pada konsentrasi tertinggi yaitu $1000 \mu \mathrm{g} / \mathrm{mL}$ jumlah kematian sel terlihat lebih banyak daripada jumlah kematian sel pada konsentrasi 125 dan $15,625 \mu \mathrm{g} / \mathrm{mL}$, sel mati terlihat berbentuk bulat jernih dan sel hidup terlihat lonjong. Sebagaimana ditunjukkan pada gambar Gambar 2.

Morfologi sel hasil treatment tidak terlihat jelas akibat warna sampel uji masih terlalu pekat dan menutupi morfologi selnya, sehingga perlu dicuci dengan penambahan PBS untuk menghilangkan sisa media dan menghilangkan warna pada sampel uji. Analisa ini merupakan analisa awal sebelum sel ditambahkan reagen MTT, sedangkan setelah sel ditambahkan reagen MTT kematian sel dapat diamati secara kasat mata, karena terjadi reaksi kolorimetri. Sel hidup mampu mengadsorbsi garam tetrazolium (reagen MTT) dan dipecah menjadi kristal formazan oleh sistem suksinat tetrazolium reduktase yang terdapat dalam jalur respirasi sel, sehingga reagen MTT yang awalnya berwarna kuning akan berubah menjadi ungu (formazan), sedangkan pada sel mati akan tetap berwarna kuning.

Intensitas warna ungu yang dihasilkan digunakan sebagai analisis kualitatif kematian sel, semakin pekat warna ungu yang dihasilkan maka semakin banyak jumlah sel hidup yang bereaksi dengan reagen MTT, sebaliknya jika warnanya semakin pudar (kuning) semakin sedikit sel yang bereaksi dengan reagen MTT atau sel mati. Hasil kuantitatif diperoleh dari nilai absorbansi menggunakan ELISA reader pada panjang gelombang $595 \mathrm{~nm}$. Penggunan panjang gelombang $595 \mathrm{~nm}$ karena warna yang tampak pada larutan adalah ungu kebiruan yang akan menyerap warna kuning dari spektra sinar tampak (Effendy, 2007).

Tabel 2. Nilai $\mathrm{IC}_{50}$ uji aktivitas antikanker daun rumput bambu

\begin{tabular}{|l|c|}
\hline \multicolumn{1}{|c|}{ Sampel } & $\mathbf{I C}_{\mathbf{5 0}}(\boldsymbol{\mu \mathbf { g }} / \mathbf{m L})$ \\
\hline Ekstrak etanol 80 \% & 321,389 \\
\hline $\begin{array}{l}\text { Ekstrak etanol hasil } \\
\text { hidrolisis }\end{array}$ & 481,984 \\
\hline Fraksi kloroform & 177,852 \\
\hline Fraksi n-Heksana & 300,681 \\
\hline
\end{tabular}

Semakin besar absorbansi menunjukkan semakin banyak jumlah sel hidup (Meiyanto, dkk., 1999). Potensi aktivitas sampel uji dianalisis menggunakan program SPSS 16.0 analisis probit untuk mengetahui nilai $\mathrm{IC}_{50}$ pada setiap sampel. Hasil IC I0 $_{0}$ ditunjukkan pada Tabel 2.

Fraksi kloroform memiliki nilai $\mathrm{IC}_{50}$ terendah, yang artinya dalam konsentrasi $177,852 \mu \mathrm{g} / \mathrm{mL}$ mampu menghambat proliferasi sel sebanyak $50 \%$. Menurut National Cancer Institute (NCI) dalam Rahmawati (2013) suatu ekstrak dinyatakan aktif memiliki aktivitas antikanker apabila memiliki nilai $\mathrm{IC}_{50}<30 \mu \mathrm{g} / \mathrm{ml}$, moderat aktif apabila memiliki nilai $\mathrm{IC}_{50} \geq 30 \mu \mathrm{g} / \mathrm{ml}$ dan $\mathrm{IC}_{50}<100 \mu \mathrm{g} / \mathrm{ml}$ dan dikatakan tidak aktif apabila nilai $\mathrm{IC}_{50}>100$, sehingga diketahui fraksi kloroform tidak aktif sebagai agen antikanker, begitu juga dengan ekstrak etanol, ekstrak hasil hidrolisis, dan 
fraksi n-Heksana yang tidak memiliki potensi dalam menghambat pertumbuhan sel kanker payudara dikarenakan nilai $\mathrm{IC}_{50}$ yang tinggi.

\section{Pemisahan Senyawa Aktif Secara Kromatografi Lapis Tipis Preparatif (KLTP)}

Pemisahan senyawa aktif dengan KLTP dilakukan pada fraksi kloroform karena mempunyai nilai $\mathrm{IC}_{50}$ terendah. Kandungan golongan senyawa aktif fraksi kloroform dari hasil uji fitokimia adalah tanin dan steroid, sehingga eluen yang digunakan pada proses elusi senyawa steroid adalah n-heksana:etil asetat (7:3) dan untuk senyawa tanin menggunakan nheksana:etil asetat (6:4). Hasil pemisahan KLTP dan nilai Rf disajikan pada tabel 3 dan 4.

Hasil pemisahan golongan senyawa steroid diperoleh 17 noda, dugaan senyawa steroid adalah noda yang berwarna ungu dan hijau setelah dideteksi dibawah lampu UV $366 \mathrm{~nm}$. Penelitian sebelumnya (Handayani, dkk., 2008) hasil KLT golongan senyawa steroid dengan pereaksi Lieberman-Burchard menunjukkan terbentuknya noda berwarna hijau. Ungu sampai coklat setelah disemprot pereaksi Lieberman-Burchard dan dideteksi dibawah lampu UV $366 \mathrm{~nm}$ (Saleh, 2009). Sedangkan golongan senyawa tanin diperoleh 11 noda dan dugaan senyawa tanin adalah noda yang berwarna lembayung dan ungu.
Tabel 3 Hasil pemisahan golongan senyawa steroid

\begin{tabular}{|c|c|c|c|}
\hline Noda & Nilai Rf & Warna noda & Dugaan senyawa \\
\hline 1 & 0,08 & Merah muda & - \\
\hline 2 & 0,15 & Merah muda & - \\
\hline 3 & 0,22 & Merah muda & - \\
\hline 4 & 0,27 & Ungu & Steroid \\
\hline 5 & 0,33 & Merah muda & - \\
\hline 6 & 0,41 & Ungu & Steroid \\
\hline 7 & 0,47 & Ungu & Steroid \\
\hline 8 & 0,53 & Merah muda & - \\
\hline 9 & 0,59 & Merah muda & - \\
\hline 10 & 0,71 & Ungu & Steroid \\
\hline 11 & 0,75 & Ungu & Steroid \\
\hline 12 & 0,80 & Ungu & Steroid \\
\hline 13 & 0,83 & Merah muda & - \\
\hline 14 & 0,84 & Ungu & Steroid \\
\hline 15 & 0,87 & Hijau & Steroid \\
\hline 16 & 0,92 & Merah muda & - \\
\hline 17 & 0,96 & Hijau & Steroid \\
\hline
\end{tabular}

Tabel 4 Hasil pemisahan golongan senyawa tanin

\begin{tabular}{|c|c|c|c|}
\hline Noda & Nilai Rf & Warna noda & Dugaan senyawa \\
\hline 1 & 0,05 & Merah muda & - \\
\hline 2 & 0,16 & Lembayung & Tanin \\
\hline 3 & 0,28 & Merah muda & - \\
\hline 4 & 0,45 & Merah muda & - \\
\hline 5 & 0,58 & Merah muda & Tanin \\
\hline 6 & 0,64 & Lembayung & - \\
\hline 7 & 0,78 & Merah muda & Tanin \\
\hline 8 & 0,84 & Merah muda & Tanin \\
\hline 9 & 0,88 & Lembayung & Tanin \\
\hline 10 & 0,93 & Ungu & Ungu \\
\hline 11 & 0,97 & \multicolumn{2}{c|}{} \\
\hline
\end{tabular}

Noda-noda yang didapatkan dari KLTP dikerok dan dilarutkan dalam etanol p.a, kemudian disentrifugasi untuk memisahkan silika gel dengan senyawa aktif yang terlarut pada etanol p.a. Filtrat yang diperoleh diidentifikasi dengan spektrofotometer UV-Vis dan FTIR.

Identifikasi Golongan Senyawa Aktif dengan Spektrofotometer UV-Vis dan Spektrofotometer FTIR

Isolat yang diduga senyawa steroid adalah isolat 10 yang memiliki satu garis spektra pada panjang gelombang $279,1 \mathrm{~nm}$. Hal ini didukung dengan hasil penelitian Susilowati (2011) Spektra UV hasil isolasi daun rimbang mempunyai serapan maksimum pada panjang gelombang 271 $\mathrm{nm}$ dan $281 \mathrm{~nm}$. Maksimum pada panjang gelombang $271 \mathrm{~nm}$ menunjukkan adanya ikatan rangkap yang terkonjugasi.

Hasil identifikasi dengan FTIR menunjukkan bahwa dugaan steroid terdapat pada fraksi kloroform memberikan beberapa serapan penting, yaitu pita serapan 
utama gugus $-\mathrm{O}-\mathrm{H}$ alkohol pada bilangan gelombang $3462,7 \mathrm{~cm}^{-1}$, pada bilangan gelombang 2921,2 dan 2852,6 $\mathrm{cm}^{-1}$ menunjukkan serapan uluran $\mathrm{C}-\mathrm{H}$ metilen, pada bilangan gelombang 1732,8 $\mathrm{cm}^{-1}$ menunjukkan serapan $\mathrm{C}=\mathrm{C}$ alkena pada luar cincin aromatis, pada bilangan gelombang 1577,7 dan 1543,5 $\mathrm{cm}^{-1}$ menunjukkan serapan $\mathrm{C}=\mathrm{C}$ alkena pada cincin aromatis, pada bilangan gelombang 1463 dan 1384 $\mathrm{cm}^{-1}$ menunjukkan serapan metilen tekuk dan $\mathrm{C}-\mathrm{H}$ tekuk metil.

Isolat yang diduga senyawa tanin adalah isolat 9, memiliki satu garis spektra pada panjang gelombang 331,6 $\mathrm{nm}$. Penelitian Sa'adah (2013) tentang isolasi dan identifikasi senyawa tanin yang menunjukkan isolat dugaan senyawa tanin memiliki satu garis spektra pada panjang gelombang $331 \mathrm{~nm}$ dan hasil identifikasi senyawa tanin dari tanaman mimosa yang sebagai standar dari tanin karena memiliki kadar tanin cukup banyak, memiliki satu garis spektra pada panjang gelombang 318 nm. Serapan isolat 9 pada panjang gelombang maksimum 331,6 nm ini diduga karena adanya transisi elektronik dari $\pi-\pi^{*}$ yaitu pada ikatan $\mathrm{C}=\mathrm{C}$ aromatik.

Hasil identifikasi dengan FTIR enunjukkan bahwa dugaan tanin terdapat pada fraksi n-heksan memberikan beberapa serapan penting, yaitu pita serapan gugus $\mathrm{O}-\mathrm{H}$ alkohol pada bilangan gelombang $3482 \mathrm{~cm}^{-1}$, pada bilangan gelombang 2926 dan $2859 \mathrm{~cm}^{-1}$ menunjukkan serapan uluran $\mathrm{C}-\mathrm{H}$ metilen, pada bilangan gelombang $1735 \mathrm{~cm}^{-1}$ menunjukkan serapan $\mathrm{C}=\mathrm{C}$ alkena pada cincin luar aromatis, pada bilangan gelombang $1649 \quad \mathrm{~cm}^{-1}$ menunjukkan serapan $\mathrm{C}=\mathrm{C}$ alkena pada cincin aromatis, pada bilangan gelombang 1458 dan $1384 \mathrm{~cm}^{-1}$ menunjukkan serapan metilen tekuk dan C-H tekuk metil.

\section{KESIMPULAN}

Ekstrak etanol $80 \%$, ekstrak hasil hidrolisis, fraksi kloroform dan fraksi n-heksana daun rumput bambu (Lophaterum gracile $\mathrm{B}$.) memiliki nilai $\mathrm{IC}_{50}$ berturut-turut 321,$4 ; 482,0 ; 177,8$; dan $300,7 \mu \mathrm{g} / \mathrm{mL}$. Ekstrak etanol $80 \%$ memiliki aktivitas sangat lemah, ekstrak etanol hasil hidrolisis sangat lemah, fraksi kloroform lemah, dan fraksi n-heksana sangat lemah dalam menghambat pertumbuhan dan membunuh sel kanker payudara T47D

Hasil uji fitokimia, identifikasi dengan spektrofotometer UV-Vis dan FTIR fraksi kloroform dan n-heksana daun rumput bambu (Lophaterum gracile B.) yang memiliki nilai $\mathrm{IC}_{50}$ paling rendah mengandung senyawa aktif golongan tanin dan steroid.

\section{DAFTAR PUSTAKA}

Burdall, S.E., Hanby, A.M., Lansdown, M.R,. dan Speirs, V. 2003. Breast cancer cell lines : friend or foe. Breast Cancer Research, 5, 89-95.

CCRC. 2009. Prosedur Tetap Uji Sitotoksik Metode MTT. Yogyakarta: Fakultas Farmasi, UGM.

Effendy. 2007. Perspektif Baru Kimia Koordinasi Jilid I. Malang: Banyu Media Publishing.

IARC (International Agency for Research on Cancer). 2010. GLOBOCAN 2008 Fast Stats. France: GLOBOCAN (IARC) Section of Cancer Information (2/7/2014). http://globocan.iarc.fr/factsheet.asp Diakses tanggal 2 Juli 2014. 
Jing, Z., Ying, W., Xiao-Qi, Z., QingWen, Z., dan Wen-Cai, Y. 2009. Chemical Constituents from the Leaves of Lophatherium gracile.

China. Chinesse Journal of Natural Medicines, 7(6): 428431.

Kaur, N. and Murphy, J.B. 2012. Enhanced Isoflavone Biosynthesis in transgenic Cowpea (Vigna unguiculata I) Callus. UrbanaCampaign, USA: University of Illinois Departement of Crop Sciences. Academy Journal-Plant Mol Biol Biotechnol 2012 3(1):18.

Kusumaningtyas, E., Astuti, E., dan Darmono. 2008. Sensitivitas Metode Bioautografi Kontak dan Agar Overlay dalam Penentuan Senyawa Antikapang. Jurnal ilmu kefarmasian. Fakultas Farmasi Universitas Pancasila. Vol. 6, No. 2.

Kusumawati, I., Djatmiko, W., dan Rahman, A. 2003. Eksplorasi Keanekaragaman dan Kandungan Kimia Tumbuhan Obat di Hutan Tropis Gunung Arjuno. Jurnal Bahan Alam Indonesian Volume 2 (3).

Mc. Laughlin J.L. 1991. Crown Gall Tumours on Potato Disc and Brine Shrimp Lethality: Two Simple Bioassay for Higher Plant Screening and Fractination. Methods in Plants Biochemistry, Academic Press.
Meiyanto, M., Kudo, G., Lee, Y., Yang, T.J., Gelboin, H.V., Gonzalez, F.J. 1999. Targeted Disruption of the Microsomal Epoxide Hydrolase Gene. The Journal of Biological Chemistry. 274. 23963-23968.

Nihlati, I., Abdul, R. dan Triana, H. 2008. Daya Antioksidan Ekstrak Etanol Rimpang Temu Kunci (Boesenbergia pandurata S.) dengan Metode Penangkapan Radikal DPPH (1,1-difenil-2pikrilhidrazil). Skripsi Diterbitkan. Yogyakarta: Universitas Gadjah Mada.

Rahmawati, Emma, dkk. 2013. Aktivitas Antikanker Ekstrak n-Heksana dan Ekstrak Metanol Herba Pacar Air (Impatiens balsamina Linn) terhadap Sel Kanker Payudara T47D. Media Farmasi Vol. 10 No.2.

Restasari, A., Kusrini, K., dan Fachriyah, E. 2009. Isolasi dan identifikasi Fraksi Teraktif dari Ekstrak Kloroform Daun Ketapang (Terminalia catappa Linn). FMIPA Kimia UNDIP. Semarang.

Saleh, C. 2009. Identifikasi Senyawa Steroid dari Kulit Batang Tumbuhan Maja (Aegle Marmelos (L) Correa). Kimia Mulawarman. Volume 5 (2): 24-27.

Sari, S.P. dan Hayati, E.K. 2014. Aktivitas Sitotoksik ekstrak Kasar Daun Rumput Bambu 
(Lophatherum gracile B.) Terhadap Larva Udang Artemia salina leach Dan Identifikasi Awal Senyawa Aktifnya. Skripsi. Tidak Diterbitkan. Fakultas Sains dan Teknologi Universitas Islam Negeri Maulana Malik Ibrahim Malang.
Susilowati., Indriati, H., Limra, W. Isolasi Dan Identifikasi Senyawa Steroid Dari Daun Rimbang (Solanum torvum). Prodi Pendidikan Kimia Jurusan PMIPA FKIP. Universitas Riau Pekanbaru. 